\title{
Method vs. Metaphysics
}

\section{The Notion of Substance and the Emergence of Scientific "Neutrality" in Descartes}

\author{
Han van Ruler \\ Erasmus University Rotterdam, Rotterdam, The Netherlands \\ vanruler@esphil.eur.nl
}

\begin{abstract}
This article discusses Descartes's preferred focus on morally and theologically neutral subjects and points out the impact of this focus on the scientific status of theology. It does so by linking Descartes's method to his transformation of the notion of substance. Descartes's Meditations centred around epistemological questions rather than non-human intelligences or the life of the mind beyond this world. Likewise, in his early works, Descartes consistently avoided referring to causal operators. Finally, having first redefined the notion of substance in the Principia, Descartes would completely abandon making use of this notion in his later years. Indeed, in contrast to many authors before and after him, Descartes never showed any interest in the long-established metaphysical interpretation of substances as being causal factors of natural change. With God, nature, and mind commonly serving as instances of substantial causality, Descartes's philosophy had a huge impact on the place of God in science and discreetly excluded theology as a subject to which his method might be applied.
\end{abstract}

\section{Keywords}

metaphysics - mind - substance - science - God - theology - method

\section{Introduction}

In a letter to Pierre Chanut of the 1st of November 1646, Descartes confesses that moral philosophy was "a subject" that he "must not get involved in writing about." We may read this comment in a variety of ways. In one sense, it confirms Descartes's often-repeated desire to keep clear of philosophical controversy. We 
may also see it as an indirect excuse to Queen Christina for the kind of natural questions that he had thus far presented as the primary field of his intellectual interests. Yet more importantly with respect to the immediate context in which the remark was made, it is equally indicative of Descartes's acute awareness of the existence of a morally neutral field of philosophising; a domain of science invulnerable to moral or religious criticism.

Instead of simply declaring moral philosophy not to be his thing, Descartes's decision to avoid moral philosophical debate is here presented as a conscious decision, related to the fact that moral philosophy did not promise any certainty of truth. Though disciplinary boundaries might often be trespassed by others, Descartes makes clear he had no intention himself to engage in it. Indeed, referring to the "slander" of "Messieurs les Regens" (presumably a reference to the Utrecht authorities), and to the accusations of scepticism and atheism that had been addressed to him by Father Bourdin and Dominee Voetius, Descartes's words to Chanut leave no doubt as to his own conviction of the political and religious neutrality of the subjects he had always dealt with, his own view being that he did not even come close to the kind of risk involved in the moral issues these false accusations implied. ${ }^{1}$

In what follows, I shall want to examine in what manner and to what extent Descartes's philosophical position is indeed suggestive of the historical demarcation of a new domain of disinterested scientific inquiry. My focus shall be on metaphysical issues relevant to the separation of the philosophical and theological domains, and I shall argue that it was in fact metaphysics itself that Descartes sought to evade, as well as the kind of moral questions that accompany a metaphysical view on things, rather than moral philosophy as such.

\section{Descartes on Forms and Substances}

Reassuring Chanut that the kind of sciences he had dealt with simply had no bearing on politics or religion, Descartes, in his letter, sums up some of the more sensitive things he might have touched instead:

What would they [i.e., his critics: the Utrecht City Council, Bourdin, Voetius] not say if I [i.e., Descartes] undertook to examine the right value of all the things we can desire or fear, the state of the soul after death,

1 Descartes to Chanut, 1 November 1646, AT IV 536-537; CSM K 299. 
how far we ought to love life, and how we ought to live in order to have no reason to fear losing our life?

Some of these questions seem to suggest philosophical themes that Descartes was already in the process of becoming less anxious to tackle from a new, physiological, perspective - but in fact, the way in which they are formulated suggests that according to Descartes they were just as much irresolvable as the famous question of the state of the soul after death. His refusal to deal with the latter question, moreover, had already marked the novelty of Descartes's own dealings with the discipline he sometimes called "philosophy," but more often "first philosophy" or "metaphysics," a discipline he had, in fact, unrecognisably transformed with the publication, in 1641, of his Meditations.

For a seventeenth-century book on metaphysics, Descartes's Meditations were spectacularly silent on the question of immortality. Whilst the question was still of central importance to academic as well as to popular works of metaphysics, Descartes showed no interest at all in the things that were routinely discussed with respect to the activity of the soul after death. Indeed, the absence of a discussion on the anima separata in Descartes is an important facet of the way in which his dealings with the soul were driven by an interest in the notion of what he calls "thought" - i.e., what we would call 'consciousness' — as well as to the epistemological question of the reliability of experience-but all of this to the complete demise of an interest in the disembodied metaphysical entity of the soul itself. ${ }^{3}$

This in itself was a revolution with respect to the subject-matter of metaphysics, but it is a revolution that cannot be understood independently of a more general disregard of metaphysical entities in the earlier Descartes. Indeed, the new orientation of Descartes's metaphysics and its indifference to the soul as the object of metaphysical investigation has a background in his preliminary rejection of metaphysical entities in physics, and it is to these that I shall turn first: to the notions, that is, of forms and substances.

Besides expressing himself to be disinclined to elaborate on moral philosophical themes in the 1640s, Descartes had already shown himself reluctant to discuss any type of metaphysical question in the early 1630 . Convinced of the fact that allowing for the activity of metaphysical factors of change was

2 Ibid.

3 See my "La découverte du domain mental: Descartes et la naturalisation de la conscience," Noctua 3 (2016-2; online 14 August 2017), 239-294, http://www.didaschein.net/ojs/index.php/ noctua/index, there 270-284, where I offer works by Jean de Silhon and Franco Petri Burgersdijk, respectively, as examples of a popular and an academic treatise on metaphysics. 
irrelevant for explaining natural processes, Descartes had deliberately aimed to avoid getting entangled in scholastic metaphysical debates, sometimes excusing himself by saying he had no wish "to break the peace with the philosophers."

It was, more specifically, his refusal to take into account the 'natures' or 'substantial forms' of things, and his concomitant rejection of the notion of 'real qualities,' that distinguished Descartes's philosophy from the philosophies of his contemporaries, and on account of this resulted in what, pace Daniel Garber, we might describe as Descartes's surprisingly 'non-metaphysical' physics.

Content with keeping a philosophical truce, danger of war for Descartes lay in the touchy subject of the metaphysics of forms-a subject on which he did not wish to argue, but nevertheless showed where his preferences lay on every page. In fact, for Descartes, there were two ways of being non-metaphysical in physics: as there was no need for substantial forms in physics proper, neither was there any need, according to Descartes, for souls in physiology, i.e., in the explanation of the animal body. Both with respect to physiological questions and with respect to the subject of nature at large, Descartes's unpublished early works thus mark a clear turning point in seventeenth-century scientific thought. His crucial step is no longer to make use of the idea of active principles as the metaphysical factors that may be held responsible for natural change.

The consequences of this step, however, extended far beyond the initial questions of cosmology and physiology. Stripping both inanimate nature and living bodies of their active forms, Descartes's way of doing physics implied the exclusion of God, nature and the human soul, as well as of other metaphysical factors of causality, from the explanations of natural processes; thereby effectively giving occasion to the way in which such metaphysical agents would be given new roles in Descartes's mature philosophy and science.

To see this, it will be of interest to consider to what extent Descartes was willing to meet scholastic metaphysical needs when, in the early 1640 , he finally took up the challenge to confront the philosophers. Faced with an onslaught of theological criticism, Descartes decided to address the philosophers after all - not with the publication of his Meditations, but with the publication of his Principia, the book that, as his Summa philosophiae, he explicitly intended

4 AT VI, 239. On the successive stages of Descartes's intellectual focus, see my article "Philosopher defying the Philosophers: Descartes's Life and Works," in The Oxford Handbook of Descartes and Cartesianism, ed. Steven Nadler, Tad M. Schmaltz, and Delphine AntoineMahut (Oxford, 2019), 3-24. 
to be his decisive answer to the likes of Bourdin and Voetius and to work as a means for drawing benevolent scholastics to his side. ${ }^{5}$

What do we find in Descartes's Summa with respect to the replacement or transformation of scholastic metaphysical notions? Naturally, no attention is given in the Principia to the notions of 'substantial form' or 'real qualities', but it is striking that at least the notion of substance - a notion Descartes had already made ample use of in the Meditations - is given a new place within the context of Descartes's alternative form of philosophical analysis. Principia I 51 famously defines 'substance' in terms of independence, although it also argues against the univocal applicability of this term. A substance is "a thing which exists in such a way as to depend on no other thing for its existence," but Descartes adds that this definition does not imply that there is any "distinctly intelligible meaning" of the term that is "common to God and his creatures."

Substantiality, in other words, does not bind God and other "substantial" things in such a way as to be indicative of even the most abstract of similarities between them. What follows, accordingly, is in no way a reinstallment of the old notion of substantiality, or a reinstitution of the traditional way in which metaphysical factors of change formed part of the description of natural phenomena. Descartes's notion of substance, by contrast, has only a very limited use. In the Principia, it functions primarily as a way to emphasize the idea that, amongst the phenomena we may conceptualize, we recognize only two sorts of things: "created thinking substance" on the one hand and "corporeal substance" on the other. ${ }^{7}$ In accordance with this, the "natures" of these two versions of created substance are explicitly said to be completely absorbed by their various attributes: thought and extension. As a follow-up, Descartes makes clear that this leaves no room for an abstract notion of substance that might function in any other way than for us to make what Descartes presents as being a "conceptual distinction" - the distinction between the attributes we recognize

5 Cf. Descartes to Mersenne, January 1642, AT III 523 / CSMK 209-210. See also Van Ruler, "Philosopher defying the Philosophers," (see above, n. 4), 16.

6 René Descartes, Principia philosophiae I 51, AT VIII-I 24 / CSM I 210. Curiously, the French edition adds to the text of this paragraph a definition with respect to "created things" in scholastic terms, restoring the traditional way of seeing things in terms of substances next to qualities and attributes, but this is an add-on that has no bearing either on the immediate context or on what follows.

7 Cf. Descartes, Principia I 54, AT VIII-I 25 / CSM I 211. 
and the things we conclude must exist on the basis of our ability to distinguish such attributes. ${ }^{8}$

What is important about this very cautious handling of the notion, is that even if the notion of substance thus, in Descartes's own philosophy, evokes the idea of "real things" behind the appearance of attributes - and potentially even of metaphysical beings - he still refuses to make use of the idea that substances might serve to function as metaphysical principles of natural change. More than that, Descartes does not even care to establish what, in the end, may count as individual substances at all. Is it the physical universe as a whole, our minds, in as far as we experience these individually, constellations of things or thoughts, or any other type of physical or mental domain? Descartes's Summa simply offers no answer to this.

The absence of any such answers, moreover, is not just indicative for the way in which Descartes's philosophical position does not lend itself to the schoolbook type of summaries we are apt to make on its basis; it is also indicative of the very absence of metaphysical topics in Descartes. Indeed, in Descartes, the substance-mode ontology functions only as a way of dealing with the separation of distinct domains of philosophical inquiry. It is, in other words, only the existence of incongruous properties that offers experiential confirmation of an ontological divide, which turns the concept of 'substance' itself into an experiential Grenzbegriff, and in fact a very meagre concept in ontological terms. It is as if the cautious tripartition of experiential fields that Descartes would later offer in his answer to Princess Elisabeth's metaphysical queries, is already prepared in the twofold division of domains Descartes presents in Principia I 63. ${ }^{9}$

More important is what is thereby left out. What we do not find in Descartes-neither in the Principles, nor in any other of his works-is a notion of substance that meets the two requirements of substantiality philosophers had traditionally associated with the notions of 'substance' and 'form': the idea of causal activity, namely, combined with the idea of individuality. A substance, in other words, served as a metaphysical ground for the idea that an active force takes care of the activation of nature (or of parts of nature), combined with the idea of a metaphysical identity that might be acknowledged as the bearer of such force. As for activation, the only metaphysical argument we find

8 Descartes, Principia I 63, AT VIII-I 30-31 / CSM I 215.

9 Challenged by Elisabeth to explain how the soul might determine the body to perform voluntary actions (AT II 661), Descartes answered that all one can do, is to distinguish between physical, mental, and combined phenomena (i.e., phenomena of mind-body interaction) on the basis of our inborn 'notions' of all of these kinds of events, without reducing any one of them to the other. Cf. Descartes to Elisabeth, 21 May 1643, AT III 663-668 / cSM K 217-220. 
in Descartes is the hypothesis that the clockwork of nature must once have been set into motion by God. ${ }^{10}$ Yet nowhere do metaphysical identities enter the description of natural processes themselves. Likewise, neither is the idea of the individuality of bodily objects anchored in any metaphysical principle of substantial unity.11

\section{$4 \quad$ Non-Cartesian and Quasi-Cartesian Substances}

It can hardly be overemphasized to what extent this "Baconian" type of metaphysical restraint, which I presume may otherwise be found only in materialist contexts, is an exceptional philosophical position within the seventeenthcentury mind-set. Other novatores, both before and after Descartes, and both of non-Cartesian and Cartesian backgrounds, might still call for a notion of substantiality that did comply to an Aristotelian ontological outlook and to Aristotelian ontological demands. To offer some examples of alternative philosophies-philosophies that reverted to traditional conceptions of substantiality, we might point, first, to non-Aristotelian philosophies that might still call for alternative principles. Examples may be found in the many Renaissance philosophies that introduced a choice collection of either classical elements, alchemical principles, or more Platonizing conceptions of active identities, such as the notion of a "World Soul.'12

10 The idea occurs as one of a series of suppositions in Chapter 6 of René Descartes, Le monde ou Traité de la lumière, AT XI 34 / CSM I 91 in particular, as well as in Principia II 36, AT VIIII 61-62 / CSM I 240, where God is presented as "the primary cause of motion."

11 As Geneviève Rodis-Lewis emphasized back in 1950, "Cartesian philosophy does not provide (...) any principle ensuring the intrinsic individuation of material objects" so that "the apparent individuality of material objects is ultimately based on no substantial identity." Geneviève Lewis, L'Individualité selon Descartes (Paris, 1950), 59 and 6o, respectively.

12 Even Francis Bacon distinguished between active, though material, forms of 'spirit' and passive forms of 'tangible essence' as stand-ins for the causal roles of Aristotelian forms and matter. Cf., e.g., Novum Organum II 7. Other principles equally sought to provide natural explanations either in terms of active spiritual and passive material principles, or in material substances that were distinguished according to their envisioned active and passive causal roles. In alchemy, the threesome of sulphur, mercury, and salt might represent active, passive, and mediate factors, or active and passive factors in dual combinations. As Lawrence Principe has written: "Theories about matter and its composition-Zosimo's "soul and body," Jābir's Mercury and Sulfur, Gerber's minima, Paracelsus's tria prima, the Scholastic's prime matter and substantial form, Van Helmont's semina, and all the restundergirded alchemical aims and directed practical laboratory endeavors." Cf. Lawrence M. Principe, The Secrets of Alchemy (Chicago, 2013), 207. For further examples, as well as for some of the other philosophies discussed further on in this section, see also my arti- 
Early in the century, moreover, David Gorlaeus (1591-1612), though a fierce anti-Aristotelian who has been seen as a pioneer in chemistry as well as a forerunner in formulating what has been called the upcoming 'substance-mode ontology, ${ }^{13}$ could not fathom the idea that natural philosophy would cease to preoccupy itself with uncovering substantial, and thus causally responsible, actors of natural change. He accordingly reproduced standard scholastic maxims such as that 'accidents cannot produce a substance', defending these on the basis of the equally scholastic type of argumentation that accidents are ontologically "poorer" (vilius) and "more imperfect" than a substance—for which reason they cannot bring about anything substantial. ${ }^{14}$

We even encounter the need for a full-blown idea of substantiality popping up in Cartesian authors after Descartes. The self-appointed Cartesian physician Heydentryk Overkamp, for instance, argued against Descartes that movement must be more than a simple form of translatio or 'transfer.' It must be a 'substance' (selfstandigheyt), since, according to Overkamp "it is a contradiction to say that an accident or a hoedanigheyt" might be "a principle of change."15 Overkamp might in a sense be considered more Cartesian than Descartes himself for his way of explaining apparent situations of rest in terms of a "pressure" by the surrounding, inherently mobile, and therefore constantly pressing matter. In his commentary on the second book of the Principia of 1683, however, he is also critical of Descartes, most notably condemning the latter's idea of motion in terms of a translatio (a 'transfer' or, in Dutch: vervoering), and as a "modus of the body," arguing that in this manner, only the "effect" of movement is evoked. ${ }^{16}$ Although he next takes the unprecedented step actually to equate matter and motion, Overkamp's argumentation was likewise driven by an ontological interpretation of the notion of substantiality that reinvokes the idea that only substances may count as principles of change.

cle "Substance in Early Modern Philosophy" in the Springer Encyclopedia of Early Modern Philosophy and the Sciences, ed. Dana Jalobeanu and Charles T. Wolfe, forthcoming.

13 The Flemish-Frisian youth David van Goorle (1591-1612), a Leiden theology student, gained such renown for his atomism that Leiden University would later name its chemistry building after him. On Gorlaeus as a potential precursor of Descartes in metaphysics, see Helen Hattab, Descartes on Forms and Mechanisms (Cambridge, 2009).

14 See my article "Substantiële entiteiten zonder vorm: Gorlaeus' worsteling met Aristoteles," It Beaken: Tydskrift fan de Fryske Akademy 76 (2014), 197-228.

15 See my article "Spinoza in Leiden," in Spinoza en zijn kring: een balans van veertig jaar onderzoek, ed. Henri Krop (Rijnsburg, 2019), 31-44.

16 Heydentryck Overkamp, Nader Ondersoeck over het Tweede Deel van de Beginselen der Wijsbegeerte van Renatus Descartes (Amsterdam: J. ten Hoorn, 1683), 46-47. 
In fourth instance, we might, of course, refer to the so-called "occasionalists," who took the wholly un-Cartesian step of (re)introducing the idea of mind acting on matter as a metaphor relevant for understanding natural change. Again, it must be emphasised that such a notion of natural substances acting as principles of change is a notion not to be found in Descartes's physics, nor is it a category that plays any role in Descartes's metaphysics. The question, accordingly, whether Descartes himself was an occasionalist, is a misguided question. ${ }^{17}$ Aristotelian critics as well as occasionalist, Spinozist and Leibnizian followers of Descartes continued to be intrigued by the question 'If forms do not activate matter, what, then, does?' This, however, was a question Descartes himself consistently ignored. Although there is a strong human propensity to think that something must be responsible for action, that something must do the causal work, the very idea behind Cartesian physics is that the metaphor of mind acting on matter should no longer be considered a valid form of scientific explanation. The natural world, indeed, is matter without form.

A fifth example of a revival of metaphysical argumentation beyond Descartes may be found in Spinoza's Cogitata metaphysica. The fact itself that Spinoza saw the need to add a series of Metaphysical Thoughts of his own to his 1661 commentary on Descartes's Principles indicates to what extent he found a philosophical analysis in terms of causal entities to be missing in Descartes. Whilst these Cogitata metaphysica confer no further causal role on-or even as much as mention - the Cartesian ego, ample attention is given to an analysis of God's role in nature through his attributes; an analysis wholly complementary to anything Descartes had written in the Principia. Despite the fact that secondary literature on the Cogitata metaphysica is still scarce, and that it remains true what Theo Verbeek already said in 2003, namely that "[of] all of Spinoza's texts, the Cogitata metaphysica is the most enigmatic and the least studied,"18 we may thus take what Spinoza wished to add to his commentary on the Prin-

17 See also my article "Minds, Forms and Spirits: The Nature of Cartesian Disenchantment," Journal of the History of Ideas 61 (2000), 381-395, in which I argued against trying to decide the then much-discussed question of Descartes's own presumed "occasionalism." On occasionalism, see also Ursula Renz and Han van Ruler, "Okkasionalismus," in Enzyklopädie Philosophie, ed. Hans Jörg Sandkühler, 3 vols. (Hamburg, 2010), 2: 1843-1846.

18 Theo Verbeek, "Zijn” en "Niet-Zijn" in Spinoza's Cogitata metaphysica," in Spinoza en de scholastiek, ed. Gunther Coppens (Leuven, 2003), 91-101, there 99. Characteristic for the lack of critical historical reflections on the text of the Cogitata is, for example, the fact that the third chapter on 'The Metaphysical Thoughts' in Alexander Douglas's (otherwise interesting) book about Spinoza and Dutch Cartesianism is about anything and everything, except the Cogitata metaphysica. Cf. Alexander X. Douglas, Spinoza \& Dutch Cartesianism: Philosophy and Theology (Oxford, 2015), 64-9o. 
ciples (and thus his reasons for writing the Cogitata) to lie in the sphere of supplementing what Descartes had neglected to offer, namely, a metaphysical account of God's role in nature. ${ }^{19}$

Of course, God's role becoming more and more identified, even in the young Spinoza, with that of nature itself, there is as little room in Spinoza as there had been in Descartes for causal forms of substantiality within nature. Yet the idea that there is a need for metaphysical suppliers of causal force is reinstated in Spinoza, with God taking over this role in all things natural as the sole instantiation of a metaphysical entity that provides for a genuinely substantial support of natural activity. Crucial as this idea was to Spinoza, it would later come to be expressed in the very first proposition of his Ethics, which (in a scholastic manner reminiscent of Gorlaeus) states that "A substance is by nature prior to its attributes. ${ }^{20}$ Spinoza, in other words, restores the notion of substance to its full meaning, dressing it up in its full metaphysical attire as the ontological entity that is endowed with activation and individuality.

In similar ways, other late seventeenth-century philosophical positions also exemplified the need felt for reintroducing metaphysical forms of ontological dependency, whether this occurred in the more Aristotelian sense of reintroducing forms that provided nature with a metaphysical substructure of being and activity, or in the more Platonizing form that argued for metaphysical objects from an epistemological perspective, as in the Spinozistic account of God-given adequate insights or Malebranchean forms of a vision-en-Dieu. ${ }^{21}$ Here too, Descartes's epistemological analysis is always on the this-worldly side of human experience. Descartes might well thank God, where appropriate, for the apparently gratuitous way in which human beings are equipped with a faculty of reason enabling them to make sense of sense experience. ${ }^{22}$ He never

19 With its non-Cartesian attention to God's role in nature through his attributes, the Cogitata metaphysica provide exactly this type of additional analysis.

20 Spinoza, Ethics I 1.

21 For Malebranche's idea of 'illumination' in terms of the vision-en-Dieu, see Nicholas Malebranche, Recherche de la vérité III 6-7, ed. Geneviève Lewis (Paris, 1946), vol. 3, 248-256. For a discussion of Malebranche's epistemological steps, see, e.g., Daisie Radner, Malebranche: A Study of a Cartesian System (Assen, 1978), 52-59.

22 It must be said, however, that, in the conclusion of the Meditations, this type of gratitude comes to be expressed only implicitly where Descartes argues that, "notwithstanding the immense goodness of God," natural forms of deception are likely to occur, but may nevertheless be corrected - a consideration that is of "the greatest help to me, not only for noticing all the errors to which my nature is liable, but also for enabling me to correct or avoid them without difficulty. For I know that in matters regarding the well-being of the body, all my senses report the truth much more frequently than not. Also, I can almost always make use of more than one sense to investigate the same thing; and in addition, I 
does so, however, in order to render this into an argument in favour of the need for the mind to enter some metaphysical realm that provides an absolute foundation for the recognition of physical facts. Indeed, with respect to the vision-en-Dieu in particular, there is no reason, in Descartes, to find a metaphysical ground for providing sensible species with an interpretation. Just as there is no occasionalist need, in Descartes, for a metaphysical grounding of change, there is neither any Spinozistic or Malebranchean-type of need for a metaphysical grounding of knowledge apart from the epistemological project of being able to give a coherent interpretation of experience.

Without pursuing to add to the list of non-Aristotelian revivers of substance theory such obvious metaphysical revisionists as Gottfried Wilhelm Leibniz, let us simply note that beyond Descartes, seventeenth-century intellectual history would witness a series of quick — though ultimately short-lived — revivals of a metaphysical way of seeing things in which the question 'if forms do not activate matter, what, then, does?', led to a restoration of the metaphysically charged interpretation of substantiality that Descartes himself consistently ignored. ${ }^{23}$ The reason is every time the same: there is a strong human propensity to think that there must be something responsible for natural activity! Something, in other words, must do the causal work. The very idea, however, behind Cartesian natural philosophy had been that the metaphor of mind acting on matter could no longer be considered a valid form of scientific explanation - which is why we do not find a similar propensity in Descartes. Again, for him, the natural world, at least as far as we might understand it, was matter without form.

\section{Theology without Substance}

Similarly, the notions of God and the 'I', too, are virtually stripped of their metaphysical roles in Descartes, the reason being that his philosophical interest does not extend to the kind of questions later rehabilitators of the substances, forms, and essences may have tried to answer on the basis of such metaphysical footings. I cannot here go into all the aspects in which Descartes's Meditations deviated from traditional metaphysics by being a primarily epistemological and

can use both my memory, which connects present experiences with preceding ones, and my intellect, which has by now examined all the causes of error." Cf. Descartes, Meditations, AT VII 88 and 89, respectively / CSM II 61.

23 See also my article on "Substance in Early Modern Philosophy," in the Springer Encyclopedia of Early Modern Philosophy and the Sciences (see above, n. 12). 
neurophysiologically driven project, but it may suffice to point to the absence of such issues as an enumeration of divine attributes, for instance, or the question of immortality, to point out only some of the most striking differences of scope between Descartes's metaphysics and the science of metaphysics as it had traditionally been conceived - let alone that we might find in Descartes such Spinozistic themes as the notion of a science of ethics culminating in the idea of spiritual ecstasy on the basis of the tried and tested theological notion that mental ecstasy involves combining a full necessitarianism to an act of love. ${ }^{24}$

Yet even if there is no metaphysical concept of nature in Descartes, is it not true that Descartes himself continued to make use at least of the metaphysical entities of the 'I' and of God? Is it not obvious to any reader of the Meditations, that both the 'I' and God play crucial roles in the build-up of its argumentation? The relevant answer here, must be that yes, the 'I' as well as God are very prominent in Descartes's work of metaphysics, but they are never the subject-matter of philosophical investigation in the way treatises on the metaphysica specialis traditionally treated and explained their position on God, the soul, angels, and the like. In this sense, the Meditations are in fact silent on both the nature of God and the nature of the human soul.

Indeed, the naturalisation of mental experience is such a central theme in Descartes that even within the Meditations, a book that deals primarily with the epistemological question of human intellectual fitness, the soul comes to function as an introspective basis for understanding psychosomatic processes, rather than for understanding anything about the soul itself. This is also what will remain Descartes's prime focus during the later 1640s: to provide for a theory of the passions on the basis of a pragmatic interpretation of the interaction of body and soul - a neurophysiological interest that we do not find in authors who put a ban on the idea of mind-body interaction for metaphysical reasons. In this sense, Descartes again has no qualms with completely ignoring any treatment of the 'I' in terms of a metaphysical object.

The same, moreover, is true for God. According to Michael Della Rocca, a core aspect of Descartes's notion of God, is that it presents us with the idea of a being at once "all-powerful," but yet "non-threatening":

24 On the relationship between Spinoza and early modern theology, see my article "Beatitude and the Scope of Grace: Early-Modern Morals and the Paradoxes of Felicity," in Inexcusabiles: Salvation and the Virtues of the Pagans in the Early Modern Period [Archives internationales d'histoire des idées 229], ed. Alberto Frigo (Cham, 2020), 107-123; https:// doi.org/10.1007/978-3-030-40017-o. 
Descartes' general strategy $[\ldots]$ is ingenuous: in positing this all-powerful, but non-threatening God, i.e. in insulating claims about God's power from what might be thought to be their standard implications concerning the features of created beings, Descartes is paving the way for philosophical inquiry into worldly matters [...] to proceed unfettered by worries about placing illegitimate limitations on God's power. Although God obviously plays a central role in Descartes' philosophy, we can see that, with this strategy, Descartes takes a big step towards the view—which was to be so influential later - that the nature and qualities of God have no straightforward bearing on the kinds of philosophical claims we can legitimately reach concerning finite objects. ${ }^{25}$

Della Rocca presents this "general strategy" as a conscious approach Descartes exhibits in dealing with a combination of philosophical themes, also including his way of arguing against the univocity of divine and finite being and of pleading for God's creation of eternal truths. In all such cases, however, there is a common thread to be found in Descartes's way of setting aside the notion of God in the scientific description of finite things. Avoiding any understanding of entities in terms of their inner forces, Descartes's separation of God and creation is in fact nothing else than a further instance of his general disinclination to refer to the metaphysical presence of a substantial agent in the explanation of things natural.

\section{Voetius's Nightmare}

If Descartes's natural philosophy itself would not stand the test of time, there is still much in his philosophy to be considered of lasting importance. Half-way down the nineteenth-century, August Comte had no misgivings about presenting an already canonised Descartes as the harbinger of positivism. Comte's reason for doing so was that Descartes had been the philosopher who had purified scientific methodology by eliminating metaphysical beings from nature. Thus, in his Discours surl'espritpositif of 1844 , the book in which Comte pinned down to a specific era of intellectual development what he interpreted as the birth of the 'positive' sciences, René Descartes emerges, together with Bacon, as the forerunner of positivism because, in Comte's words, he had "decisively

25 Michael Della Rocca, "René Descartes," in A Companion to Early Modern Philosophy, ed. Steven Nadler (Oxford, 2002), 6o-79, esp. 71-73, there 73 . 
undermined the entire domain of entities (tout le régime des entités)." ${ }^{26}$ Comte's insightful way of bringing into perspective René Descartes's contribution to scientific ways of thinking, is marked not so much by what Descartes himself brought forward in terms of physical theory, but rather by what he did away with in order to get there. For Comte, rejecting an Aristotelian ontology was in fact characterised by a rejection and disqualification of causal entities.

If, today, we discuss questions of orthodoxy and heterodoxy in respect of seventeenth-century philosophical positions, the first thing we must get clear about with respect to Descartes, is that Descartes never showed an interest in fighting either a Protestant or a Catholic cause within philosophy. Many a commentator who has tried to define his position on the theological questions of grace and human freedom, has been bewildered by Descartes's apparent theological inconsistency. Characteristically, Étienne Gilson would even implicitly accuse Descartes of bad faith on account of his apparent indecision on dogmatic issues. Plane assentior, Descartes had told his correspondents twice with regard to grace: "I totally agree" — but what Descartes was agreeing to in these cases, were two absolutely irreconcilable positions on the question divine grace, which was the reason for Étienne Gilson to draw the conclusion that, "of these two plane assentior [affirmations], there is necessarily one too many."27

The question, however, is not quite as straightforward as this. If Descartes, at times, was willing to satisfy some Gomarist or Oratorian friend, while at other instances issuing support for Arminian or Jesuit positions, what he does in such cases is not to explain himself on some dogmatic position of theology, but to draw from contemporary debates on freedom and grace some thesis relevant to a philosophical understanding of the mental processes involved in human judgment. ${ }^{28}$ Accordingly, rather than wavering between all sorts of theological views, Descartes was putting to use theological forms of analysis in order to explain an epistemological position of his own. The theological question of freedom and grace was thereby naturalised into a theologically neutralised theory of judgement.

In other instances, too, Descartes's philosophical position carries signs of a remarkable theological indifference - an indifference that would continue to affect the reception of Cartesianism in later years. Whereas, historically, religious dissatisfaction with Descartes focused mainly on the difficulty of concep-

26 Auguste Comte, Discours sur l'esprit positif (Paris: Carilian-Goeury—Dalmont, 1844), 9.

27 Étienne Gilson, "La doctrine cartésienne de la liberté et la théologie," Bulletin de la société française de philosophie 14 (1914), 207-258, there 219: "De ces deux plane assentior il y en a nécessairement un qui est de trop."

28 Cf. my article "La découverte du domain mental" (see above, n. 3). 
tualising transubstantiation in Catholic quarters, and of understanding questions of freedom and grace in terms of a form of a cooperation between primary and secondary causes on the Protestant side, what I have tried to indicate by focusing on the notion of substance, is that the relevance of Descartes's philosophy to theology lies much deeper still. In fact, because of his reticence to give in to metaphysical considerations, the idea of giving ultimate grounds and sufficient reasons on a metaphysical level of causal explanation becomes obsolete in Descartes. Not only did the subject of theology thereby lose its scientific status, as Gisbertus Voetius foresaw and much feared, but the notion of God itself lost much of its metaphysical force.

I cannot at present go into all relevant aspects of Descartes's iconoclastic handling of the subject of metaphysics, which, besides nature and God, also involved changes of intellectually handling the notion of the soul. With respect to the issue of orthodoxy, heterodoxy, and indifference, let me summarize that, besides functioning in what was left of metaphysics as an object of consideration in establishing the conditions for human knowledge, and occupying a role as the hypothesis of fate in the context of human psychological needs, the metaphysical notion of God is by and large absent from Descartes's philosophical works.

\section{Conclusion}

One might go even further and consider what the later demise of metaphysics would eventually include. For Descartes the amateur theologian, theological forms of analysis based on a scholastic notion of analogy might still form quite an important pastime outside of his published works. Yet without its role as a factor of causation in the metaphysical grounding of reality, the notion of God could be no more than either a given, innate concept of the mind put there by our Maker, or an idea of substantiality projected on the basis of the notion we have of ourselves, provided as it is by the phenomenological realm of introspection. It is therefore no surprise that, in the long run, the idea that there were religiously neutral forms of scientific inquiry yielding trustworthy forms of knowledge that needed no grounding in the agency of metaphysical entities, would push forward psychology to replace metaphysics as a handmaiden for theology and would ultimately reduce the realm of religion more and more to human moral and psychological needs.

This is not, of course, to say that Descartes himself was in any way a fullblown positivist in the nineteenth-century sense of the word. At the same time, it would nevertheless seem appropriate to say that, despite the methodologi- 
cal insufficiency of Descartes's own scientific programme, our latter-day scientific culture shares some important characteristics with the Cartesian worldoutlook in that Descartes already combined a proto-Kantian feel for the limitedness of human cognitive capacities to a proto-Heideggerian awareness of the attachments of human thought to the everyday practice of life-and, more particularly with respect to the issues of theology and religion here discussed, already quite uncompromisingly displayed a proto-Wittgenstinian tendency towards agnosticism.

If it is in this sense that Descartes was the ultimate seventeenth-century representative of a strict separation between philosophy and theology - a separation that, to my mind, has too often and too easily been discarded as cowardly subterfuge on his part-it is historically of importance not to misjudge the intellectual relevance of this position, but to understand it in terms of the welldefined and reasonable choice that it was, at least in the face of the alternative of reverting to an old-school type of substance-metaphysics. Descartes's refusal in any way to expand on metaphysical entities and their activities was itself a form of theological indifference-an indifference that, as Descartes implied when writing to Chanut, had always been his aim, and formed part of a coherent strategy to try and find certainty only within religiously neutral domains of knowledge. 